\title{
Pengaruh Pemberian Susu Skim dengan Pengencer Tris Kuning Telur terhadap Daya Tahan Hidup Spermatozoa Sapi pada Suhu Penyimpanan $5^{\circ} \mathrm{C}$
}

\author{
Nilawati Widjaya \\ Jurusan Produksi Ternak, Fakultas Pertanian Universitas Bandung Raya \\ Jl. Banten No. 11, Bandung 40272 \\ Email:widjajanilawati@yahoo.com
}

\begin{abstract}
ABSTRAK
Tujuan penelitian untuk mengetahui pengaruh pemberian susu skim dengan pengencer Tris kuning telur terhadap daya tahan hidup spermatozoa sapi pada suhu penyimpanan $5^{\circ} \mathrm{C}$. Penelitian ini menggunakan semen Sapi Simmental. Rancangan yang digunakan adalah Rancangan Acak Kelompok (RAK) dengan 5 perlakuan dan 5 kelompok sebagai kelompok adalah ejakulat. Sebagai perlakuan : $\mathrm{P}_{0}=$ susu skim $100 \%$ tanpa pengencer Tris kuning telur; $\mathrm{P}_{1}=$ susu skim $95 \%$ + tris kuning telur 5\%; $\mathrm{P}_{2}=$ susu skim $90 \%+$ Tris kuning kuning telur $10 \% ; \mathrm{P}_{3}=$ susu skim $85 \%+$ Tris kuning telur $15 \% ; \mathrm{P}_{4}=$ susu skim $80 \%+$ Tris kuning telur 20\%. Peubah yang diamati adalah persentase hidup spermatozoa dan motilitas spermatozoa setelah disimpan selama 2 hari pada suhu $5^{\circ} \mathrm{C}$. Pemberian pengencer susu skim dengan Tris kuning telur sangat mempengaruhi persentase hidup dan motilitas spermatozoa sapi yang disimpan pada suhu $5^{\circ} \mathrm{C}(\mathrm{P}<0.01)$. Pemberian pengencer susu skim sampai taraf $15 \%$ memberikan hasil yang terbaik sehingga mampu menekan laju penurunan daya tahan hidup spermatozoa Sapi Simmental yang disimpan selama 2 hari pada suhu $5^{\circ} \mathrm{C}$.
\end{abstract}

Kata kunci : susu skim, spermatozoa, pengencer tris kuning telur, daya tahan hidup

\section{Effect of Skim Milk and Tris Yolk Extender on Viability of Bovine Spermatozoa at Temperature $5^{\circ} \mathrm{C}$}

\section{ABSTRACT}

The objective of the study was to determine the effect of skim milk and Tris yolk extender on the viability bovine spermatozoa at $5{ }^{\circ} \mathrm{C}$. This study used Simmental bull semen. The design used was Randomized Design Group (RAK) with 5 treatments and 5 groups of ejaculate. The treatments were: P0 = skim milk 100\% without Tris yolk extender; P1 = 95\% skim milk $+5 \%$ Tris yolk extender, $P 2=90 \%$ skim milk + Tris yolk extender $10 \%, P 3=$ skim milk $85 \%+$ Tris yolk extender 15\%, P4 = skim milk 80\% + Tris yolk extender 20\%. The observed variables were the percentage of live spermatozoa and the motility of spermatozoa after storage for 2 days at $5^{\circ} \mathrm{C}$. Skim milk with Tris yolk extender affect the viability and motility of spermatozoa stored at $5^{\circ} \mathrm{C}(\mathrm{P}<0.01)$. Provision of extender up to $15 \%$ gave the best results and suppressed the decline in the viability of spermatozoa storaged for 2 days at $5^{\circ} \mathrm{C}$.

Key words: skim milk, spermatozoa, Tris yolk extender, viability 


\section{PENDAHULUAN}

Salah satu upaya dalam perbaikan produktivitas ternak sapi dapat dilakukan dengan metode Inseminasi Buatan (IB). Keberhasilan Inseminasi Buatan (IB) dapat dicapai melalui kualitas semen jantan, perlakuan terhadap semen, transportasi dan pelaksanaan inseminasi, sehingga ketersediaan semen yang dibutuhkan setiap saat dalam keadaan yang masih baik serta layak untuk inseminasi dapat dilakukan dengan cara pengawetan semen yaitu dengan melakukan pengenceran semen.

Pengenceran semen dilakukan untuk mengurangi kepadatan dan menjaga kelangsungan hidup spermatozoa. Bahan pengencer tersebut mengandung zat -zat makanan sebagai sumber energi dan tidak bersifat racun bagi spermatozoa, dapat melindungi spermatozoa dari kejut dingin (cold shock), menghambat pertumbuhan mikroba serta bersifat sebagai penyangga (Djanuar, 1985).

Tris merupakan larutan yang mengandung asam sitrat dan fruktosa yang berperan sebagai penyangga (buffer), untuk mencegah perubahan $\mathrm{pH}$ akibat asam laktat dari hasil metabolisme spermatozoa serta mempertahankan tekanan osmotik dan keseimbangan elektrolit, sumber energi dan melindungi spermatozoa dari kejut dingin (cold shock). Selain itu, tris mempunyai kemampuan dalam memberikan motilitas spermatozoa yang lebih tinggi karena tris lebih banyak mengandung zat - zat makanan, antara lain fruktosa, asam sitrat yang dapat dipanaskan sebagai buffer dan meningkatkan aktifitas spermatozoa (Hoesni, 1997).

Manfaat kuning telur terletak pada lipoprotein dan lesitin yang terkandung di dalamnya (Kampschmidt dkk, 1953; Bleckshaw, 1954 dalam Toelihere 1985) yang bekerja mempertahankan dan melindungi integritas selubung lipoprotein dari sel spermatozoa (Bleckshaw dan Salisbury, 1957 dalam Toelihere 1985). Kuning telur juga mengandung glukosa yang lebih suka dipergunakan oleh sel-sel sperma sapi untuk metabolismenya daripada fruktosa yang terdapat di dalam semen (Van Tienhoven dkk, 1952 dalam Toelihere 1985). Kuning telur mengandung asam asam amino, karbohidrat, vitamin, dan mineral untuk kebutuhan hidup spermatozoa. Selain itu, di dalam kuning telur terdapat senyawa anti kejut yang berperan melindungi spermatozoa dari kejut dingin. Kuning telur juga mengandung glukosa, bermacam - maca, protein, vitamin yang larut dalam air dan lemak serta viskositasnya yang dapat menguntungkan bagi spermatozoa (Djanuar, 1985).

Sebagaimana diketahui susu skim mengandung zat nutrisi yang dapat dimanfaatkan oleh spermatozoa sebagai sumber energi. Selain itu, susu skim juga mengandung zat lipoprotein dan lesitin sehingga bisa digunakan dalam pengencer semen untuk melindungi spermatozoa dari pengaruh kejut dingin (cold shock) dan air susu juga mengandung enzim yang hancur pada waktu pemanasan dimana pemanasanair susu dia atas $80^{\circ} \mathrm{C}$ akan melepaskan gugusan sulfhydril (-SH) yang berfungsi sebagai zat reduktif yang mengatur metabolism oksidatif sperma.

Atas dasar tersebut, penulis melakukan penelitian untuk mengetahui "Pengaruh Pemberian Susu Skim Dengan Pengencer Tris Kuning Telur Terhadap Daya Tahan Hidup Spermatozoa Sapi Pada Suhu Penyimpanan $5^{\circ} \mathrm{C}$ ”.

\section{MATERI DAN METODE}

Materi penelitian adalah semen sapi Simmental yang mempunyai ciri - ciri bulu berwarna krem agak kecoklatan, bagian muka dari lutut ke bawah dan ujung ekor bewarna putih, warna putih pada bagian muka bersifat dominan dari satu ekor sapi pejantan sebanyak 5 ejakulat dengan menggunakan vagina buatan. Alat yang digunakan : vagina buatan, tabung penampung, tabung reaksi berskala, spatula, gelas ukur, lemari pendingin, pipet eritrosit, oven, termos es, mikroskop, objek glass, cover glass, aluminium foil, counter, lampu 
spiritus, dan jarum suntik. Bahan yang digunakan : susu skim, kuning telur, larutan tris, $\mathrm{NaCl} 3 \%$, $\mathrm{NaCl} 9 \%$, eosin $2 \%$, antibiotik penicillin dan streptomycin.

Penelitian ini menggunakan Rancangan Acak Kelompok (RAK) dengan 5 kelompok, sebagai kelompok adalah ejakulat, dengan 5 perlakuan.

\section{HASIL DAN PEMBAHASAN}

\section{Keadaan Awal Semen}

Gambaran awal mengenai semen sapi Simmental yang digunakan dalam penelitian ini dapat dilihat pada Tabel 1.

Dari Tabel 1 dapat dilihat bahwa hasil rataan keadaan awal semen memberikan indikasi bahwa semen sapi Simmental yang digunakan memenuhi syarat dalam proses pengenceran. Rataan volume semen pada keadaan awal sebelum perlakuan adalah 5,06 ml, hal ini sesuai dengan pendapat Toelihere (1985) yang menyatakan bahwa semen sapi normal memiliki volume $5-8 \mathrm{ml}$ dengan konsentrasi sperma antara $300-2500$ juta/ml dan jumlah motilitas spermatozoa awal sebesar 65,00\%. Rataan persentase hidup spermatozoa pada keadaan awal semen sebesar $74,68 \%$ dengan rataan motilitas spermatozoa sebesar $72,00 \%$ ini berarti rataan tersebut dapat dikategorikan baik.

\section{Pengaruh Perlakuan Terhadap Persentase Hidup Spermatozoa}

Pengaruh perlakuan terhadap persentase hidup spermatozoa dapat dilihat pada Tabel 2.

Dari Tabel 2 terlihat bahwa pemberian pengencer susu skim dengan tris kuning telur sangat nyata mempengaruhi persentase hidup spermatozoa sapi yang disimpan pada suhu $5^{\circ} \mathrm{C}(\mathrm{P}<0.01)$. Perlakuan P3 memberikan hasil terbaik diikuti perlakuan P1, P2, P0, dan P4. Kondisi ini diduga pada perlakuan P3 pengencer susu skim dengan tris kuning telur mempunyai kandungan penyangga yang terdapat dalam pengencer, yang dapat menetralisir hasil metabolism seperti asam laktat sehingga spermatozoa dapat bertahan hidup. Sejalan dengan (Hafez, 1993) bahwa tris juga berfungsi sebagai penyangga untuk mencegah perubahan $\mathrm{pH}$.

Pada P1, P2, P0, dan P4 diduga susu skim dengan tris kuning telur dalam menetralisir sisa metabolisme akibat aktifitas spermatozoa meningkat sehingga banyak spermatozoa yang mati, hal ini sejalan dengan pernyataan Djanuar (1985) terjadinya metabolisme akan mengakibatkan penimbunan sisa metabolisme, penurunan $\mathrm{pH}$ dan kehabisan bahan keperluan metabolisme, peningkatan suhu semen akan mengakibatkan kecepatan metabolisme dan aktifitas spermatozoa sehingga spermatozoa mati.

\section{Pengaruh Perlakuan Terhadap Motilitas Spermatozoa}

Pengaruh perlakuan terhadap motilitas spermatozoa dapat dilihat pada Tabel 3.

Dari Tabel 3 terlihat bahwa pengaruh pemberian pengencer susu skim dengan tris kuning telur berbeda sangat nyata $(\mathrm{P}<0.01)$ terhadap motilitas spermatozoa. Perlakuan P3 memberikan persentase motilitas spermatozoa yang lebih baik dibanding dengan perlakuan P1, P2, P0, dan P4. Hal ini diduga pada perlakuan P3 pemberian susu skim dengan tris kuning telur yang ideal dimana terjadi substitusi antara zat - zat nutrisi yang terkandung di dalam susu skim dan tris kuning telur untuk mempertahankan motilitas spermatozoa yang disimpan selama 2 hari pada suhu $5^{\circ} \mathrm{C}$.

Dari hasil rataan masing - masing perlakuan terhadap spermatozoa dapat dilihat bahwa pada perlakuan P1, P2, P4 menunjukkan kecenderungan motilitas menurun, kondisi ini diduga terjadi perubahan $\mathrm{pH}$ meskipun belum berakibat fatal terhadap spermatozoa. Berbagai bahan penyangga dapat dipakai untuk 
Tabel 1. Keadaan Awal Semen Sapi Simmental sebelum Pengenceran

\begin{tabular}{lc}
\hline \hline \multicolumn{1}{c}{ Keadaan Awal Semen } & Rataan \\
\hline Volume semen (ml) & $5,06 \pm 0,42$ \\
Persentase Hidup Spermatozoa (\%) & $74,68 \pm 2,04$ \\
Motilitas Spermatozoa (\%) & $72,00 \pm 2,73$ \\
Konsentrasi Spermatozoa (juta/ml) & $422,20 \pm 64,81$ \\
\hline
\end{tabular}

Tabel 2. Rataan Persentase Hidup Spermatozoa Sapi Simmental Setelah Penyimpanan 2 Hari

\begin{tabular}{|c|c|}
\hline Perlakuan & Rataan Persentase (\%) \\
\hline $\mathrm{P} 0$ & $46,18^{\mathrm{d}}$ \\
\hline $\mathrm{P} 1$ & $57,56^{\mathrm{b}}$ \\
\hline P2 & $51,70^{\mathrm{C}}$ \\
\hline P3 & $62,48^{\mathrm{a}}$ \\
\hline P4 & $41,16^{\mathrm{e}}$ \\
\hline
\end{tabular}

Tabel 3. Rataan Motilitas Spermatozoa Sapi Simmental Setelah Penyimpanan 2 Hari

\begin{tabular}{cc}
\hline \hline Perlakuan & Rataan Persentase (\%) \\
\hline P0 & $45,4^{\mathrm{d}}$ \\
P1 & $55,6^{\mathrm{b}}$ \\
P2 & $50,1^{\mathrm{c}}$ \\
P3 & $60,7^{\mathrm{a}}$ \\
P4 & $40,8^{\mathrm{e}}$ \\
\hline
\end{tabular}

${ }_{\text {a,b,c,d,e }}$ Superskrip yang berbeda menunjukkan perbedaan yang sangat nyata $(\mathrm{P}<0,01)$.

mempertahankan pH semen, antara lain penyanggah sitrat, tris yang dapat mempertahankan $\mathrm{pH}$ dari kejut dingin (cold shock) sehingga $\mathrm{pH}$ tidak mengalami penurunan akibat asam laktat yang berpengaruh terhadap motilitas spermatozoa. Selain itu, diduga karena pada perlakuan masih memiliki cadangan energi untuk bertahan hidup dan melakukan proses metabolisme dengan cara memanfaatkan glukosa. Hal ini sesuai dengan Frandson (1993), agar dapat melakukan pergerakan, spermatozoa membutuhkan energi untuk kelangsungan hidupnya.

Pada P0 (kontrol) rataan motilitas spermatozoa terjadi penurunan keadaan ini diduga karena pada P0 tidak terdapatnya buffer sehingga tidak dapat mempertahankan $\mathrm{pH}$ semen netral. Menurut Toelihere (1985) bahwa spermatozoa menghasilkan asam laktat dalam jumlah yang tinggi dari metabolisme fruktosa sehingga penting untuk memberikan unsur penyanggah di dalam medium.

\section{KESIMPULAN}

Berdasarkan hasil penelitian dapat disimpulkan bahwa pemberian pengencer susu skim sampai taraf $15 \%$ memberikan hasil yang terbaik sehingga mampu menekan laju penurunan daya tahan spermatozoa sapi Simmental yang disimpan selama 2 hari pada suhu $5^{\circ} \mathrm{C}$.

\section{DAFTAR PUISTAKA}

Djanuar. 1985. Fisiologi Reproduksi dan Inseminasi Buatan pada Sapi. Gajah Mada University Press. Yogyakarta.

Frandson, R.D. 1993. Anatomi dan Fisiologi Ternak (Anatomy and Physiology of Farm Animal). Terjemahan Srigandono, B dan Praseno, K. Gadjah Mada University Press. Yogyakarta. 
Hafez, E.S.E. 1993. Semen Evaluasi, Dalam E.S.E. Hafez (ed) Reproduction in farm Animal. Lea and Febiger. Philadelphia. Hal $405-423$.

Hoesni, F. 1997. Pengaruh Kadar Kuning Telur dalam Berbagai Pengencer terhadap
Kualitas Spermatozoa Domba Pasca Pembekuan Program Pasca Sarjana Universitas Padjadjaran, Bandung. Toelihere, M.R. 1985. Inseminasi Buatan pada Ternak. Penerbit Angkasa. Bandung. 